Junedi Ginting. et al. The Roasting Coffee Equipment With Automatic Temperature Control and Steam/Hot...

\title{
THE ROASTING COFFEE EQUIPMENT WITH AUTOMATIC TEMPERATURE CONTROL AND STEAM / HOT AIR DISPOSAL TO ACCELERATE COOLING PROCESS OF SUPPLY RESULTS IN VILLAGE FRUIT OF REGENCY KARO
}

\author{
Junedi Ginting ${ }^{1}$, Aditia Warman², Juliati Br Tarigan ${ }^{3}$ \\ ${ }^{1,2,3}$ Mathematic and Sains Faculty, University of North Sumatera \\ Email: edittings@yahoo.com
}

\begin{abstract}
This devotional activity has been carried out and runs well in line with the aim of assisting the community of coffee farmers in Buah Raya Village for the management of coffee beans mainly by way of roasting. The tool used is 1 set of coffee cutting equipment equipped with temperature control and exhaust vapor / hot air to accelerate the cooling process results from roasting. Testing the production of the tool is done by inserting the coffee beans to be roasting and then setting the temperature button on the equipment to the temperature used in accordance with the coffee beans are inserted, after finished activate the exhaust steam / hot air and then wait a while for the coffee beans are cold. Then move the coffee beans to the aluminum plate box as a shelter.
\end{abstract}

Keywords: The Roasting Coffee

\section{PRELIMINARY}

Buah Raya Village is bordered by West Lau Biang, BintangMeriah Village to the East, Lau Buluh Village North, Limang Village and Perbesi Village in the South. Buah Raya Village is located in KutaBuluh District Karo Regency with distance $\pm 113 \mathrm{~km}$ from Medan City.

In general, the people of Buah Raya Village have variations in cropping, including coffee plants. Coffee as a plantation product in Indonesia ranks sixth after palm oil, rubber, sugar, tea and cocoa. For Indonesian people in general, drinking coffee has become a part of everyday life, especially for the elderly and now young people and teenagers. The processing of coffee beans by residents is still done manually because of the low insight of the community related equipment for processing the coffee beans so that residents sell their coffee beans with a relatively cheap price compared to the processed coffee beans.

By using a coffee bean spinning tool which is giving USU service team to coffee farmer group in Buah Raya village, all farmers of group of coffee farmers have been able to use tools to manage coffee bean so that their selling price in market is getting better which have positive impact to increase the income of community group coffee farmers. The presence of this equipment encourages citizens' motivation to expand farming land and encourage people to plant coffee for people who have not grown coffee.Thus, the established karo coffee association is easier to break down local and international markets and conduct better assessment actions by bringing in international experts / experts due to sufficient quantity, presenting colleges / scientists to research further and utilize the coffee waste as medicine, fertilizer and animal feed.

\section{TOOLS AND MATERIALS}

1 set of coffee cutlery, platinum plate and dry coffee beans.

\section{METHOD}

OF

\section{IMPLEMENTATION}

1. Dry coffee beans are put into the roasting equipment then connected to the power source.

2. On press the ON button on the equipment.

3. Set the temperature button on the equipment to regulate the temperature of the coffee bean in the equipment. 
Junedi Ginting. et al. The Roasting Coffee Equipment With Automatic Temperature Control and Steam/Hot...

4. Wait until the temperature button on the equipment becomes off.

5. Once off is opened the equipment door then on the exit button steam / hot air.

6. Wait a few minutes until the roasting coffee bean becomes cold. After cool the roasting coffee beans are transferred to the aluminum plate box as a shelter.

7. To bend the next coffee bean then do step 1 to step 6 .

\section{RESULT AND ANALYSIS}

Equipment works well because it can be roasting coffee beans so as to reduce the water content in the coffee beans, making coffee beans become more solid than before. The longer the time of roasting then the coffee beans produced will be more dry, therefore the time and temperature factor is very influential on the roasting tool this coffee.

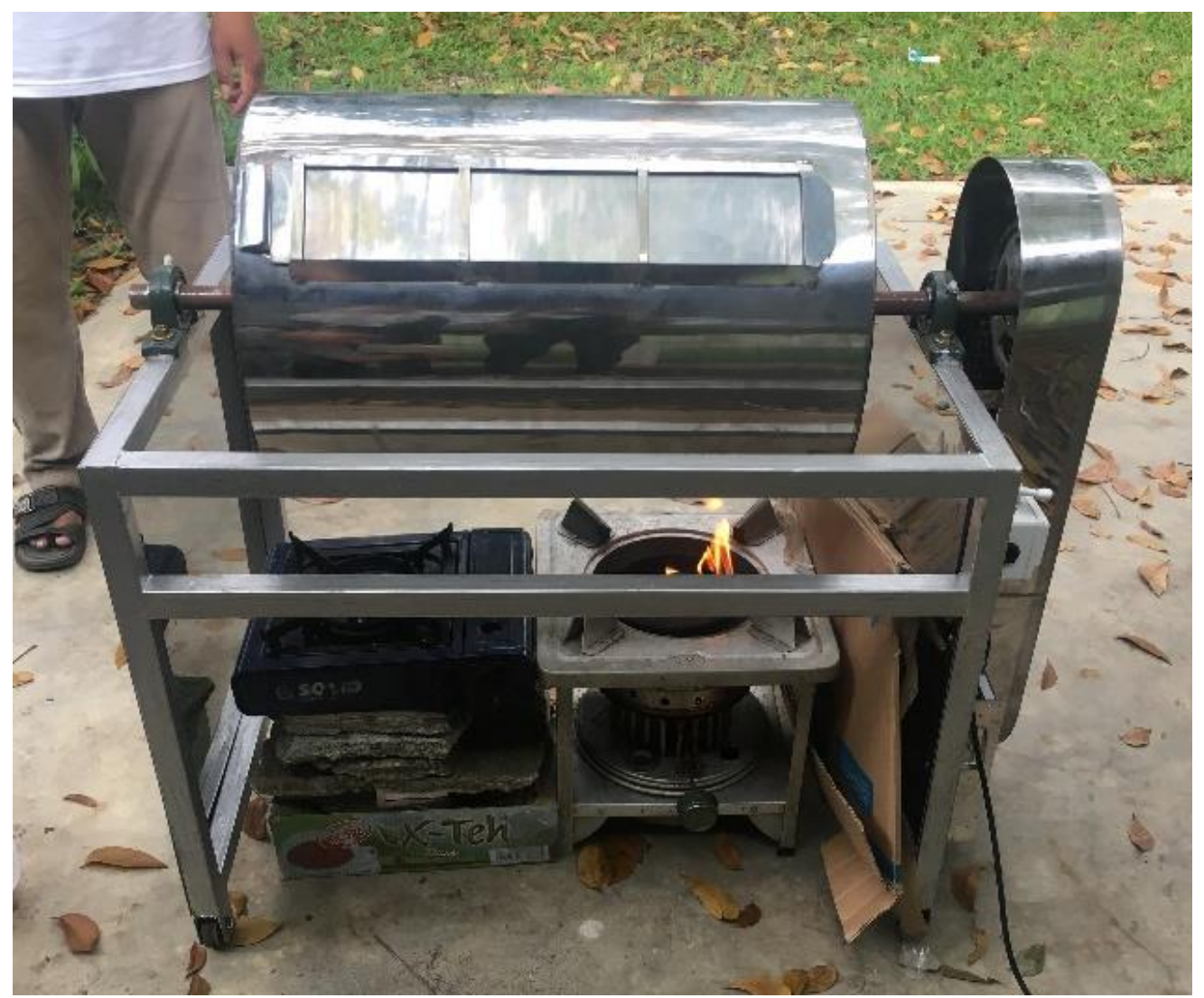

Picture. Coffee Bean Roasting Tool

After testing the coffee bean grinder using a time variation, and using a sample of $2 \mathrm{~kg}$ of dried coffee beans. From the results of sampling every 10, 20 and 30 minutes, it is obtained data on temperature changes in the coffee bean roasting machine as shown in the data table of experimental results 1 below:

Table 1. Test Result Data

\begin{tabular}{ccccc}
\hline Time & \multicolumn{4}{c}{ Temperature $\left({ }^{\circ} \mathrm{C}\right)$} \\
\cline { 2 - 5 } (minute) & $\mathrm{T}_{1}$ & $\mathrm{~T}_{2}$ & $\mathrm{~T}_{3}$ & $\mathrm{~T}_{\text {average }}$ \\
10 & $40.60^{\circ} \mathrm{C}$ & $42.87^{\circ} \mathrm{C}$ & $45.94^{\circ} \mathrm{C}$ & $43.13^{\circ} \mathrm{C}$ \\
20 & $48.85^{\circ} \mathrm{C}$ & $50.23^{\circ} \mathrm{C}$ & $52.10^{\circ} \mathrm{C}$ & $50.39^{\circ} \mathrm{C}$ \\
30 & $55.94^{\circ} \mathrm{C}$ & $58.63^{\circ} \mathrm{C}$ & $61.30^{\circ} \mathrm{C}$ & $58.57{ }^{\circ} \mathrm{C}$ \\
\hline
\end{tabular}


Junedi Ginting. et al. The Roasting Coffee Equipment With Automatic Temperature Control and Steam/Hot...

From the table above it can be seen, that the longer the holding time, the temperature of the roasting machine increases. In the experiments carried out on the coffee bean grinder, the relative temperature is quite normal, which is increasing in the range of \pm $20 \%$ per ten minutes, although the results are different but remain stable. This is because the higher the air temperature of the roasting is, the higher the heat energy carried by the air so that more and more mass of liquid is evaporated from the surface of the material. With the length of time, the temperature of the material will rise and cause the water vapor pressure in the material to be higher than the water vapor pressure in the air, resulting in the transfer of water vapor from material to air / mass transfer and added the main ingredient of the coffee bean roasting machine is stainless steel that can absorb heat well.

The combination of temperature and heating time during the roasting process through the roasting machine of coffee beans is done to avoid damage to the coffee beans. Air temperature, relative humidity, air flow, initial moisture content of the material and final content of the material are factors that affect the time or duration of grafting.

The results of the management of the coffee roasting machine also made some physical changes from the coffee beans at the time before the gongseng and after the roasted both from the level of humidity, mass, volume, resistance and discoloration of roasted coffee beans.

Table. Results of Physical Changes in Coffee Beans After Dried

\begin{tabular}{|c|c|c|c|c|c|c|}
\hline \multirow{2}{*}{ No } & \multicolumn{2}{|c|}{ HUMIDITY } & \multicolumn{2}{c|}{ MASS (kg) } & \multicolumn{2}{c|}{ VOLUME (l) } \\
\cline { 2 - 7 } & Before & After & Before & After & Before & After \\
\hline 1 & 81.00 & 80.20 & 2,00 & 1,86 & 3.42 & 3.24 \\
\hline 2 & 81.30 & 80.40 & 2,00 & 1,86 & 3.34 & 3.32 \\
\hline 3 & 80.50 & 80.50 & 2,00 & 1,86 & 3.32 & 3.37 \\
\hline Average & 80.93 & 80.36 & 2,00 & 1,86 & 3.34 & 3.1 \\
\hline
\end{tabular}

Basically it must be known that humidity levels differ from temperature. At temperatures, the lower the temperature, the higher the humidity. Conversely, the higher the temperature, the lower the humidity level. Then the level of moisture and water content contained in the coffee beans greatly affect the mass and volume of coffee beans. Overall we can know that the higher the temperature, the lower the humidity level, the mass and volume of coffee beans are also low. Depreciation that occurs in the mass of coffee beans is affected by changes in temperature over time.

With the presence of these equipment, the coffee farmers group in Buah Raya village and the neighboring village whose community cultivates coffee bordering their fields with the Buah Raya village field have all used equipment provided by the USU dedication team so that their coffee is sold to the market in the form of coffee beans before roasting and after being roasting. Where the selling price of the processed coffee beans has been more expensive than the selling price of the coffee beans before being roasted.
With the existence of tools in the village of Buah Raya result of giving the team the service of USU provide additional knowledge of coffee farming processing tehadap coffee farming communities in the village of Buah Raya also to other villages which at the time there is a party in the village of Buah Raya then the community exchange the insights / information that causes the community of the coffee farmers of Lau Buluh village inquired about the equipment to the USU service team. The result is that the coffee farming community in Lau Buluh village, Kuta Buluh District, has a coffee grinder that can be used to process coffee beans from their crops. The Lau Buluh village community gets information about this tool from the USU service team.

So the results of the activities of the USU service team is not only positive impact on the community coffee farmers group in the village of Buah Raya but a triger of coffee farmers in other villages in the District so that with this activity the USU service team managed to increase the financial income of the community to achieve welfare by utilizing the results technological development. 
Junedi Ginting. et al. The Roasting Coffee Equipment With Automatic Temperature Control and Steam/Hot...

The production of the tool shows that there are coffee beans that have different colors there are coffee beans are light-colored and also dark tones. This depends on how long the timing of the sling and how much temperature is given during the process of roasting take place. The longer the time of roasting the more dense color of coffee beans produced.

\section{CONCLUSION}

1. The combination of temperature and length of heating during the drying process through the roasting machine of coffee beans is done to avoid damage to the coffee beans.

2. The coffee beans are roasted will experience physical changes, because at the time of grinding water content of the coffee beans will be reduced this is what causes the changes in humidity, mass, volume, resistance and color.

3. The equipment that has been operated works well but it should be noted also the timing or duration of the roasting. Because it will affect the end result of coffee beans.

\section{SUGGESTION}

1. Coffee beans to be roasting it must been peeled.

2. At the roasting time of beans note the time and temperature to be used for maximum results obtained.

3. Before the roasting is begin make sure the aluminum plate is empty, because the plate will be used as a container for storage while the coffee bean after the cold.

\section{BIBLIOGRAPHY}

Astu Pudjanarsa, Ir. MT dan Djati Nursuhud, Prof.Ir. MSME, 2009. Mesin Konversi Energi,

Penerbit: Andi Publisher.

Bambang Prastowo, dkk. 2010. Budidaya dan Pasca Panen Kopi,

Pusat Penelitian dan Pengembangan Perkebunan Jakarta.

Rahmad Nurudin dan Arya Mahendra Sakti, 2014. Rancang Bangun Mesin Pengupas Kulit Kopi. JRM. Volume 01 Nomor 02 Tahun 2014. 11-15.

Syahrir Arief, 2013: PERANCANGAN MESIN PENGUPAS KULIT KOPI. Proceeding

Seminar Nasional Tahunan Teknik Mesin XII (SNTTM XII) \&

Thermofluid IV 23-24 Oktober 2013. 